Chirurgia (2018) 113: 173-184

No. 2, March - April

Copyright@ Celsius

http://dx.doi.org/10.21614/chirurgia.113.2.173

\title{
Transoral Incisionless Fundoplication (TIF 2.0): A Meta-Analysis of Three Randomized, Controlled Clinical Trials
}

\author{
Lauren Gerson ${ }^{1}$, Bruce Stouch ${ }^{2}$, Adrian Lobonțiu ${ }^{3}$ \\ ${ }^{1}$ California Pacific Medical Center, Division of Gastroenterology, San Francisco, California, USA \\ ${ }^{2}$ Biostatistics and Clinical Epidemiology Philadelphia College of Osteopathic Medicine, Philadelphia, Pennsylvania, USA \\ ${ }^{3}$ Henri Mondor University Hospital, Division of Thoracic Surgery, Creteil, Paris XII University, France
}

Corresponding author:

Adrian Lobonțiu, MD, FACS

Division of Surgery

Henri Mondor Hospital

Creteil, FRANCE

E-mail: adrian.lobontiu@gmail.com

\footnotetext{
Abbreviations:

EAE - Esophageal Acid Exposure;

ELF - Endoluminal Fundoplication;

GERD - Gastroesophageal Reflux Disease;

PPI - Proton Pump Inhibitor;

RCTs - Randomized Controlled Trials;

TIF - Transoral Incisionless Fundoplication;
}

Received: 01.04 .2018

Accepted: 20.04.2018

\section{Rezumat}

Fundoplicatura transorală fără incizii (TIF 2.0): o metaanaliză a trei studii clinice randomizate controlate

Introducere: Fundoplicatura transorală fără incizii (TIF) s-a dezvoltat ca o alternativă non-invazivă şi eficientă a tratamentului endoscopic al pacienților cu boala de reflux refractară tratamentului medical. Studiile anterioare sistematice sau metaanalize ale procedurii TIF a melanjat rezultate clinice din studii cu modalități care nu reflectă actuala şi recenta procedură TIF 2.0 dar nici selecția riguroasă a pacienților bazata pe evidențe obiective, clinice, validate anterior. Această metaanaliză a fost condusă şi designed utilizând datele clinice exclusiv a studiilor randomizate controlate care, pentru prima dată, au analizat noua tehnică TIF 2.0, procedura fiind comparată cu o cohorta de pacienți control. Obiectivul acestei metaanalize constă în faptul ca determină eficacitatea clinică şi controlul simptomelor pe durată lungă postoperator al intervenției chirurgicale TIF 2.0 în exclusivitate la pacienții care prezintă boala de reflux gastroesofagiană refractară la tratamentul optimizat cu inhibitori de pompă de protoni (IPP), incluzând rezultate obiective ca de exemplu $\mathrm{pH}$-ul esofagian, administrarea de IPP şi calitatea vieții a acestor pacienți.

Metodologie: Trei ipoteze de cercetare au fost analizate şi coroborate cu rezultatele clinice ale procedurii TIF 2.0, comparându-le cu pacienții care au rămas sub tratament optimizat cu IPP, sau placebo, tratament concomitent al bolii de reflux şi calitatea vieții raportată de pacienți cu ajutorul questionarelor validate. Evenimentele descrise au fost calculate utilizând effectul randomizat. 
Deoarece durata de urmărire post TIF 2.0 a fost variabilă, am analizat evenimentul, încorporând timpul de urmărire al fiecărui pacient, individual, la o distanță de 3 ani de la intervenția chirurgicală. Rezultate: Rezultatele acestei metaanalize, a inclus datele a 235 pacienți randomizați individual, demonstrând că aceşti subiecți analizați la 3 ani după procedura chirurgicală TIF 2.0 au obținut o ameliorare a $\mathrm{pH}$-ului esofagian, au redus considerabil medicația cu IPP şi au dezvoltat o calitate a vieții superioară.

Concluzie: În această metaanaliză în care am evaluat doar studiile randomizate controlate (RCTs), procedeul chirurgical TIF 2.0 pe pacienții cu boala de reflux refractară la IPP, produce schimbări semnificative, în comparație cu SHAM (Placebo) SAHM (IPP) în 3 aspecte: pH-ul esofagian, considerabilă diminuare a tratamentului cu IPP şi îmbunătățirea considerabilă a calitații vieții.

Cuvinte cheie: fundoplicatura transorală fără incizii, TIF 2.0, review sistematic, metaanaliză, studiu clinic controlat randomizat TIF 2.0, eficacitate pe termen lung în controlul simptomelor de reflux după procedura TIF 2.0 în pacienți cu boala de reflux cronică, rezistența la terapia optimizată cu inhibitori de pompă de protoni

\section{Abstract}

Background \& Aims: The TIF procedure has emerged as an endoscopic treatment for patients with refractory gastro-esophageal reflux disease (GERD). Previous systematic reviews of the TIF procedure conflated findings from studies with modalities that do not reflect the current 2.0 procedure technique or refined data-backed patient selection criteria. A meta-analysis was conducted using data only from randomized studies that assessed the TIF 2.0 procedure compared to a control. The purpose of the meta-analysis was to determine the efficacy and long-term outcomes associated with performance of the TIF 2.0 procedure in patients with chronic long-term refractory GERD on optimized PPI therapy, including esophageal $\mathrm{pH}$, PPI utilization and quality of life.

Methods: Three prospective research questions were predicated on the outcomes of the TIF procedure compared to patients who received PPI therapy or sham, concomitant treatment for GERD, and the patient-reported quality of life. Event rates were calculated using the random effect model. Since the time of follow-up post-TIF procedure was variable, analysis was performed to incorporate the time of follow-up for each individual patient at the 3-year time point.

Results: Results from this meta-analysis, including data from 233 patients, demonstrated that TIF subjects at 3 years had improved esophageal $\mathrm{pH}$, a decrease in PPI utilization, and improved quality of life.

Conclusions: In a meta-analysis of randomized, controlled trials (RCTs), the TIF procedure data for patients with GERD refractory to PPI's produces significant changes, compared with sham or PPI therapy, in esophageal $\mathrm{pH}$, decreased PPI utilization, and improved quality of life.

Key words: Transoral Incisionless Fundoplication, TIF 2.0, Systematic Review, Meta-Analysis, Randomized Controlled Clinical Trials TIF 2.0, efficacy and long-term outcomes associated with performance of the TIF 2.0 procedure in patients with chronic long-term refractory GERD on optimized PPI therapy

\section{Introduction}

Gastroesophageal reflux disease (GERD), is a common condition in the United States (US), affecting approximately $10 \%$ of patients on a daily or weekly basis (1). Current options for 
treatment include lifestyle modifications with weight loss, limiting consumption of fatty foods, and elimination of late-night meals being the most effective modalities (2); proton pump inhibitor (PPI) medications provide the greatest symptomatic relief as options for medical therapy. While Nissen fundoplication has shown durability up to 10 years, common, new-onset side effects in up to $30 \%$ of patients have included dysphagia, gas-bloat syndrome, and inability to belch (3). Endoscopic therapy remains a desirable alternative therapy for patients who want to eliminate or reduce medical therapy and do not want to undergo invasive surgical therapy with known associated long-term side effects.

The EsophyX device used in the Transoral Incisionless Fundoplication (TIF 2.0) procedure was cleared by the US Food and Drug Administration in 2007. Throughout the past 11 years, a significant volume of clinical data has been published which has initiated reviews by clinical societies. The Society of American Gastrointestinal and Endoscopic Surgeons (SAGES) issued a review of endoluminal treatments for GERD in which TIF 2.0 was strongly recommended for control of GERD symptoms. The American Society of General Surgeons (ASGS) and the American Gastroenterological Association (AGA) issued coverage statements in support of the procedure for a select patient population.

The TIF 2.0 procedure provides an opportunity to create a partial fundoplication via an endoscopic approach. Of approximately 20,000 cases performed to date, $95 \%$ have been performed using the TIF 2.0 procedure, the latest evolution of the procedure (see Table 1), indicated for patients with GERD partially responsive to PPI therapy and with hiatal hernias less than or equal to 2 centimeters axial and transverse dimension size. Less than five percent (approximately 850 cases) were completed using earlier iterations of the procedure [endoluminal fundoplication (ELF) and TIF 1.0] that are no longer performed. The TIF 2.0 procedure is significantly different from its precursors; during a single insertion of the device, it performs esophagogastric plications around the intra-abdominal abdominal lengthened esophagus (as opposed to gastro-gastric plications performed in ELF or TIF 1.0), the apposed fundus is wrapped around the distal esophagus, secured with fasteners placed above the Z-line (as opposed to below the Z-line), with an average of more than 20 fasteners (instead of 10 or 12).

Data from published studies comparing the TIF procedure to high dose PPI therapy or sham upper gastrointestinal (GI) endoscopy procedure with a maximum dose of PPI therapy have shown improved esophageal $\mathrm{pH}$, decrease in PPI utilization, and overall improvement in quality of life; however, some of these earlier published analyses included data from studies using earlier iterations of the TIF procedure, specifically ELF, (which consisted of gastro-gastric plications below the $\mathrm{Z}$ line) and devices that should have been excluded, as they are not used anymore. To assess the outcomes of our own research against the published data, a 2-step approach was undertaken in which a meta-analysis was conducted with data from 3 randomized studies that assessed the TIF 2.0

Table 1. Procedure evolution

\begin{tabular}{|c|c|c|c|c|c|c|c|}
\hline Procedure & Introduction & $\begin{array}{l}\text { \# Cases } \\
\text { to Date }\end{array}$ & $\begin{array}{c}\% \text { of Total } \\
\text { Cases }\end{array}$ & $\begin{array}{l}\text { Plication } \\
\text { Type }\end{array}$ & $\begin{array}{l}\text { Fastener } \\
\text { Placement }\end{array}$ & $\begin{array}{l}\text { Avg. \# of } \\
\text { Fasteners }\end{array}$ & Wrap \\
\hline $\begin{array}{l}\text { Transoral Incisionless } \\
\text { Fundoplication } 2.0 \\
\text { (TIF 2.0) }\end{array}$ & 2009 & 19,161 & $95.7 \%$ & Esophagogastric & $\begin{array}{l}1-3 \mathrm{~cm} \text { above Z-line; } \\
\text { more length along the } \\
\text { greater curve of the stomach }\end{array}$ & 12 to 23 & Yes \\
\hline $\begin{array}{l}\text { Transoral Incisionless } \\
\text { Fundoplication } 1.0 \\
\text { (TIF 1.0) }\end{array}$ & 2007 & 673 & $3.4 \%$ & Esophagogastric & Above Z-line, $1 \mathrm{~cm}$ & 12 & No \\
\hline $\begin{array}{l}\text { EndoLuminal } \\
\text { Fundoplication (ELF) }\end{array}$ & 2005 & 186 & $0.9 \%$ & Gastrogastric & Below Z-line & 10 & No \\
\hline
\end{tabular}


procedure compared to a control. The purpose of the meta-analysis was to determine the efficacy and long-term outcomes associated with performance of the TIF 2.0 procedure in patients with chronic long-term refractory GERD on optimized PPI therapy, including esophageal $\mathrm{pH}$, PPI utilization, and quality of life. Secondly, a comprehensive literature review was conducted with the aim of identifying and comparing other reports of randomized controlled trials.

\section{Methods}

\section{Statistical Methods and Analyses}

There were three prospective research questions that formed the basis for conducting the metaanalysis, given that the collective populations from the individual studies would provide greater statistical power to differentiate response. The research questions were predicated on the outcome of the TIF 2.0 procedure with EsophyX device compared to patients who received PPI therapy or sham (with or without PPI medication), concomitant treatment for GERD, and the patient- reported quality of life.

Research Question 1.0: Is there a significant difference in the proportion of patients with an esophageal $\mathrm{pH}<3$ (reclined) and an esophageal $\mathrm{pH}<5.3$ (upright) between TIF 2.0 and non-TIF 2.0 treated patients?

Research Question 2.0: Is there a significant difference in the use of PPIs over time between TIF 2.0 and non-TIF 2.0 treated patients?

Research Question 3.0: Is there a significant difference in the patient reported quality of life over time between TIF 2.0 and non-TIF 2.0 treated patients?

Categorical variables, such as gender, were summarized using counts and percentages. Continuous variables, such as the age of the patient at the time of enrollment, were summarized using descriptive statistics (number of patients, mean, standard deviation, median, range, and 95\% confidence intervals). Comparisons between TIF 2.0 and non-TIF 2.0 patients for categorical variables, such as the percentage of patients with a $\mathrm{pH}<4$ for $<3 \%$ of the time, were compared using a 2-tailed Fisher's exact test. Variables recorded on a continuous scale were compared between TIF 2.0 and non-TIF 2.0 patients using an analysis of variance test. Probability values $<0.05$ were considered significant; probability value $\geq 0.05$ but $<0.1$ were considered highly suggestive of a significant difference. All analyses were conducted using SAS (version 9.4).

\section{Literature Review}

We performed a systematic review of the existing medical literature on the TIF 2.0 procedure with EsophyX device using an expert librarian and searching PubMed and Scopus from 2008 to 2017. We included randomized controlled trials (RCTs) that randomized patients either to the TIF 2.0 procedure, PPI therapy, or sham (with or without PPI medication). Outcomes assessed included esophageal $\mathrm{pH}$, PPI utilization and quality of life.

The initial electronic search retrieved 120 references (see Graphic 1). Of those, 20 were selected for full-text review. After the final screening, 3 published studies met the inclusion criteria. One RCT4 that otherwise would have met the inclusion criteria, was ultimately excluded because it included patients with large hiatal hernias (Hill Grade III or IV), which are contraindications for the TIF 2.0 procedure. No abstracts or unpublished studies met the inclusion criteria.

\section{Results}

Three sponsored studies, also published, contributed data to the meta-analysis.

The TIF EsophyX vs Medical PPI Open label study (TEMPO) (5) is a multi-center, randomized, open-label, controlled trial comparing the efficacy of TIF 2.0 against maximum standard dose PPI therapy for controlling GERD symptoms in patients with small hiatal hernias. The primary outcome was elimination of daily troublesome regurgitation or extraesophageal symptoms. Secondary outcomes were normaliza- 


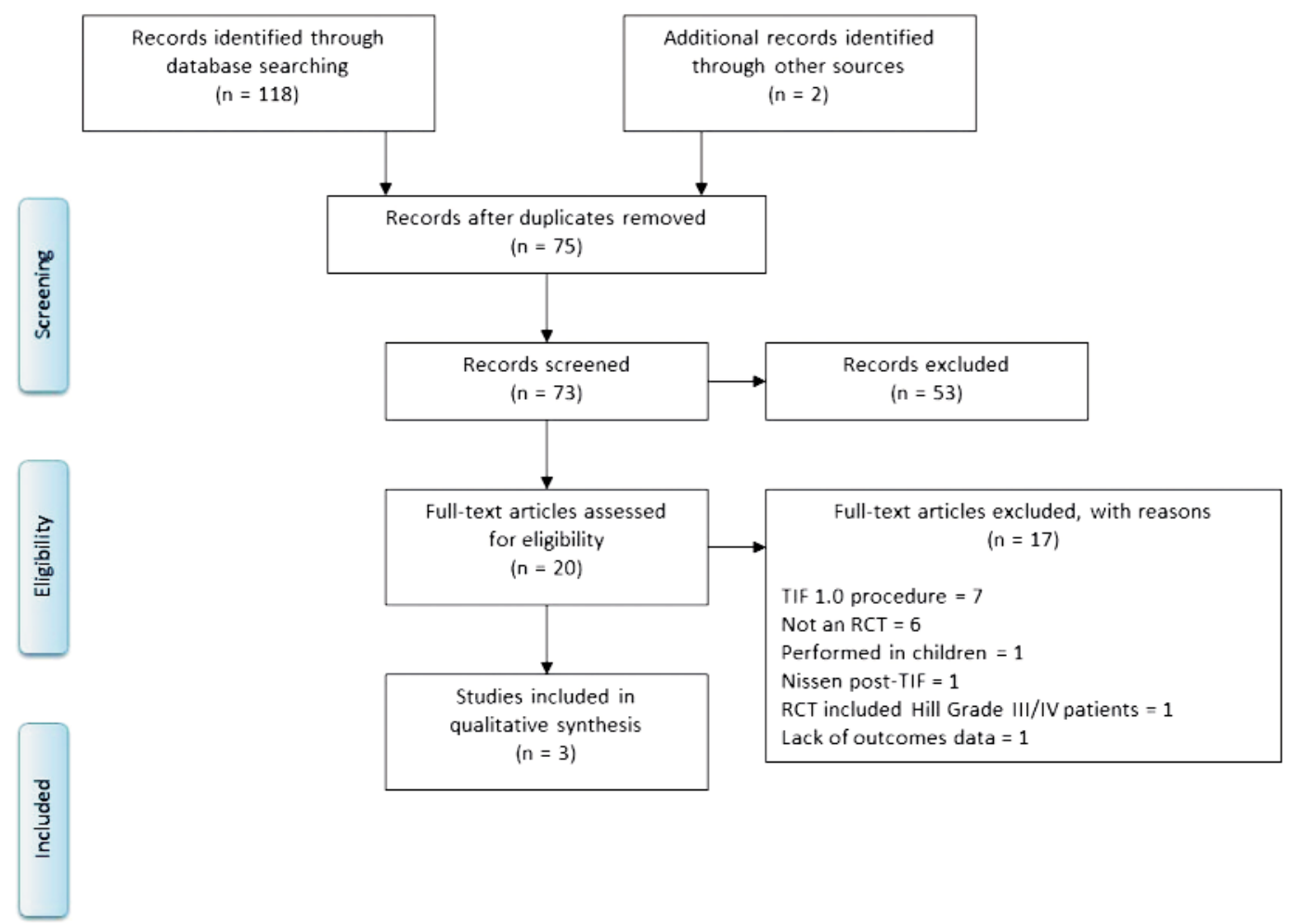

Graphic 1. Prisma diagram showing selection of studies

tion of esophageal acid exposure (EAE), PPI usage, and healing of esophagitis. Sixty-three patients were randomized at seven United States (US) academic and community hospitals (40 TIF 2.0 and 23 PPI); however, three patients were lost to follow-up, leaving 39 TIF 2.0 and $21 \mathrm{PPI}$ evaluable patients for analysis. At 6-months, the PPI therapy group was crossed over into the TIF 2.0 group. The TEMPO study has since reported at 12 -months (6) and three years (7). Patients experiencing persistent daily troublesome regurgitation or extraesophageal GERD symptoms (with or without heartburn) on daily PPIs were deemed eligible for the study if they had documented abnormal EAE as determined by ambulatory 48-hour $\mathrm{pH}$ monitoring while off PPI therapy for at least 7 days (\% total time $\mathrm{pH}<4$ occurred for $>5.3 \%$ of the recording time) and hiatal hernia measurements not exceeding $2 \mathrm{~cm}$ in both axial length and in greatest transverse dimension. EAE by 48-hour $\mathrm{pH}$ monitoring was recorded at screening, $6 \mathrm{M}$, $12 \mathrm{M}, 24 \mathrm{M}$ and $36 \mathrm{M}$.
The Randomized EsophyX vs Sham, PlaceboControlled Transoral Fundoplication (RESPECT) study (8), was a multi-center, randomized, singleblind, controlled trial comparing the efficacy of TIF 2.0 procedure and placebo against sham treatment and PPI therapy. The primary outcome was the relief of troublesome regurgitation as defined by the Montreal consensus. Secondary outcomes included early failure (defined as moderate to severe regurgitation at any time $>12$ weeks after surgery and after a doubling of medication, PPI, or placebo PPI), control of intra-esophageal acid exposure, improvement in various symptom scores (particularly heartburn), healing of esophagitis, common side effects associated with treatment (bloating and dysphagia), and severe adverse events. One-hundred and twenty-nine patients were randomized at eight academic and community hospitals across the US (87 TIF 2.0/placebo and 42 sham/PPI). Patients with troublesome regurgitation despite daily PPI use with three validated GERD-specific symptom 
scales, on and off PPIs were deemed eligible. Those with at least troublesome regurgitation (based on the Montreal definition) on PPIs underwent barium swallow, esophagogastroduodenoscopy (EGD), 48-hour esophageal $\mathrm{pH}$ monitoring (off PPIs), and high-resolution esophageal manometry analyses. Patients with GERD and hiatal hernias $\leq 2 \mathrm{~cm}$ were randomly assigned to one of the treatments.

The third study, published by Håkansson et al (9), was a multi-center, double-blind, shamcontrolled randomized trial comparing the efficacy of TIF 2.0 against a sham procedure in GERD patients who were chronic PPI users. The primary outcome was the time to 'treatment failure' during the first six months postintervention. A patient was deemed a 'treatment failure' if she/he stated a need to return to a daily, single-dose of PPIs or if there were post-interventional complaints requiring medical action, post-operative death within 30 days after TIF 2.0 procedure, moderate or severe dysphagia requiring further treatment or reoperation. Secondary outcomes included frequency and intensity of GERD symptoms assessed by the Quality of Life in Reflux and Dyspepsia (QOLRAD) questionnaire and Gastrointestinal Symptom Rating Scale (GSRS), PPI usage, EAE, healing of reflux esophagitis, Hill grading and the side-effects of the respective intervention. Patients were treated in five European centers, with 22 in the TIF 2.0 arm and 22 in the sham one. Inclusion criteria for the study included: age 18-80 years, on daily PPIs for $>6$ months, documented as 'PPI-dependent', persistent GERD symptoms without PPI therapy, evidence of two or more of the following while off PPI therapy (>10 days), erosive esophagitis (Los Angeles grade A, B or C), abnormal ambulatory $\mathrm{pH}$ study, moderate to severe GERD symptoms, and normal or near normal esophageal motility (by manometry or impedance).

The demographic results by study are combined and presented in Table 2, showing no significant differences among any of the demographic characteristics across the studies.

Table 2. Demographics

\begin{tabular}{|c|c|c|c|c|}
\hline Age (years) & RESPECT (N=129) & TEMPO $(\mathrm{N}=60)$ & Håkansson (N=44) & Combined Results $(\mathrm{N}=233)$ \\
\hline Mean \pm SD & $51.2 \pm 13.41$ & $51.5 \pm 10.28$ & $53.3 \pm 15.38$ & $51.4 \pm 13.37$ \\
\hline Median & 53.2 & 52.0 & 59.7 & 53.3 \\
\hline \multirow[t]{2}{*}{ Range } & 22.7 to 75.0 & 27.0 to 72.0 & 21.8 to 76.8 & 21.8 to 76.8 \\
\hline & Probability value compar & mean age of the $p$ & mong the three studies & 0.6749 \\
\hline \multicolumn{5}{|l|}{ Height (in.) } \\
\hline Mean \pm SD & $67.5 \pm 4.09$ & $66.7 \pm 4.02$ & $67.5 \pm 3.37$ & $67.3 \pm 3.96$ \\
\hline Median & 67.0 & 67.0 & 67.7 & 67.0 \\
\hline \multirow[t]{2}{*}{ Range } & 58.0 to 76.0 & 58.0 to 75.0 & 62.2 to 77.2 & 58.0 to 77.2 \\
\hline & Probability value compari & mean height (in.) & tients among the three $s$ & 0.3900 \\
\hline \multicolumn{5}{|l|}{ Weight (lbs.) } \\
\hline Mean \pm SD & $178.9 \pm 31.98$ & $181.8 \pm 35.73$ & $172.8 \pm 24.46$ & $178.6 \pm 31.93$ \\
\hline Median & 177.0 & 177.0 & 171.6 & 177.0 \\
\hline \multirow[t]{2}{*}{ Range } & 114.0 to 267.0 & 107.0 to 275.0 & 110.0 to 215.6 & 107.0 to 275.0 \\
\hline & Probability value compari & mean weight (lbs. & atients among the three & 0.3694 \\
\hline \multicolumn{5}{|c|}{ BMI $\left(\mathrm{kg} / \mathrm{m}^{\star \star 2}\right)$} \\
\hline Mean \pm SD & $27.6 \pm 3.85$ & $28.5 \pm 3.87$ & $26.7 \pm 3.39$ & $27.7 \pm 3.81$ \\
\hline Median & 27.6 & 28.6 & 26.8 & 27.7 \\
\hline \multirow[t]{2}{*}{ Range } & 20.3 to 38.9 & 20.2 to 37.6 & 18.6 to 33.8 & 18.6 to 38.9 \\
\hline & Probability value compari & ean BMl $\left(\mathrm{kg} / \mathrm{m}^{\prime}\right.$ & e patients among the th & 0.0461 * \\
\hline
\end{tabular}

*Patients in the TEMPO study had a significantly higher BMI compared to patients in the Hekansson study. The BMI of patients in the RESPECT study did not differ between the BMI of patients in the TEMPO study and the Håkansson study.

Note: The summary statistics presented in the table are based on the patients with recorded data. 
Table 3. pH screening

\begin{tabular}{llcccc}
\hline Time Point & & Threshold & $\begin{array}{c}\text { TIF 2.0 } \\
\text { Proportion [\%] (95\% CI) }\end{array}$ & $\begin{array}{c}\text { Sham / PPI } \\
\text { Proportion [\%] (95\% CI) }\end{array}$ & p-value \\
\hline \multirow{2}{*}{ Screening } & Upright & $<5.3$ & $19 / 148[12.84](7.9$ to 19.3) & $7 / 52[11.86](4.9$ to 22.9) & 1.000 \\
& Recline & $<3.0$ & $67 / 144[46.53](38.2,55.0)$ & $25 / 59[42.4](29.6$ to 55.9) & 0.6428 \\
\multirow{2}{*}{6 Months } & Upright & $<5.3$ & $45 / 156[28.85](21.9$ to 36.6) & $8 / 63[12.69](5.7$ to 23.5) & 0.0141 \\
& Recline & $<3.0$ & $86 / 154[55.84](47.6$ to 63.8$)$ & $26 / 63[41.3](29.0$ to 54.4$)$ & 0.0538 \\
\hline \multirow{2}{*}{12 Months } & Upright & $<5.3$ & $44 / 158[27.85](21.0$ to 35.5$)$ & $10 / 63[15.87](7.9$ to 27.3$)$ & $<0.0001$ \\
& Recline & $<3.0$ & $84 / 156[53.85](45.7,61.9)$ & $25 / 63[39.68](27.6$ to 52.8$)$ & 0.0731 \\
\hline
\end{tabular}

\section{Quality Assessment}

The overall quality of the included studies as determined by JADAD (10) methodology varied from low, in the case of TEMPO and RESPECT, to high for Håkansson et al. prone to high risk of bias. Håkansson et al. provided details on randomization sequence generation, blinding of patients, and outcome assessors. All included studies provided details on random error (i.e., sample size calculations, a and $b$ error, and expected difference).

\section{Esophageal pH Measurements}

The results of the analyses comparing the results from the $\mathrm{pH}$ test [esophageal $\mathrm{pH}<3$ ] in Table 3 revealed a higher proportion of patients with an esophageal $\mathrm{pH}<3$ in the PPI group $(64 \%)$ compared to the patients who underwent the TIF procedure (52\%). While not significant, directionally the results are encouraging for TIF 2.0 treated patients. Figures 1 and 2 further illustrate a marked improvement in $\mathrm{pH}$ for TIF 2.0 patients versus control.

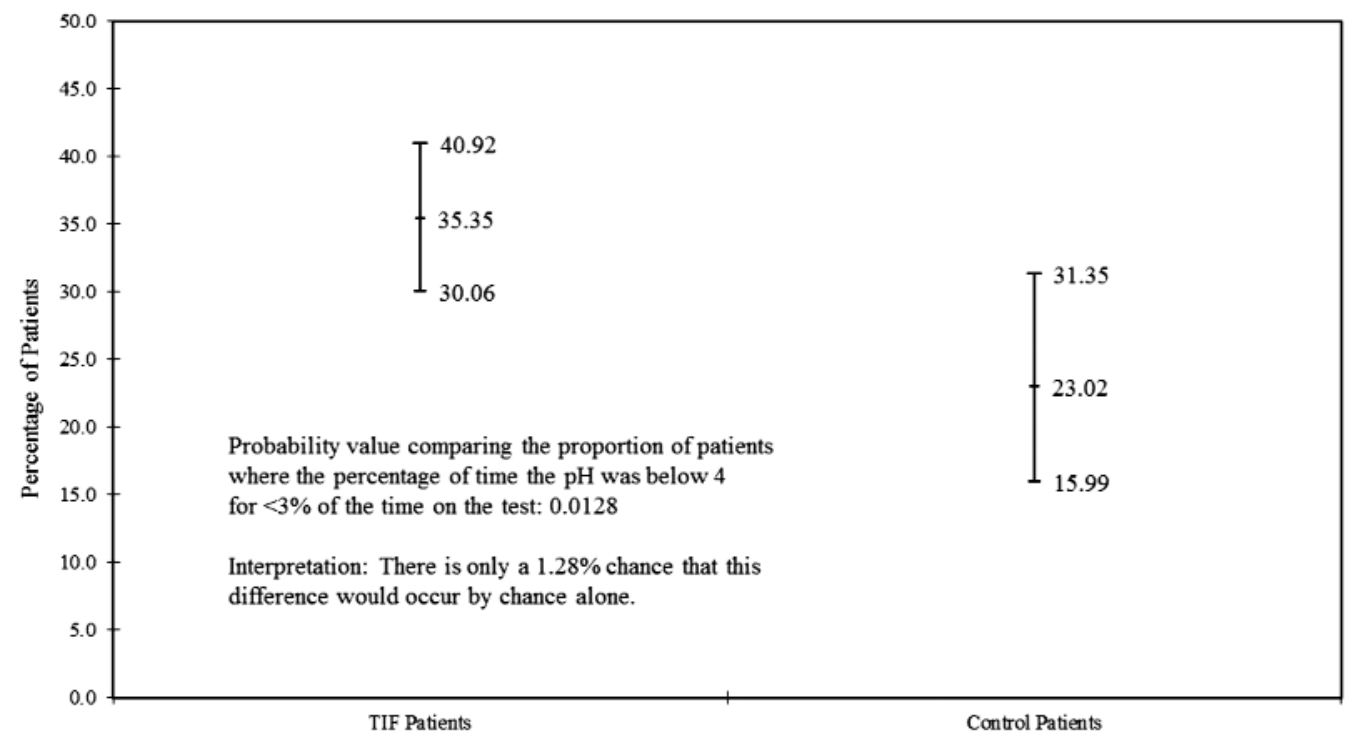

Figure 1. $\quad \mathrm{pH}$ Test Results/Reclined Position/Percentage of Patients Who had a pH Below $4<3 \%$ of the Time on the Test (Percentage with 95\% binomial confidence intervals/2-sided probability value from the Fisher's exact test) 


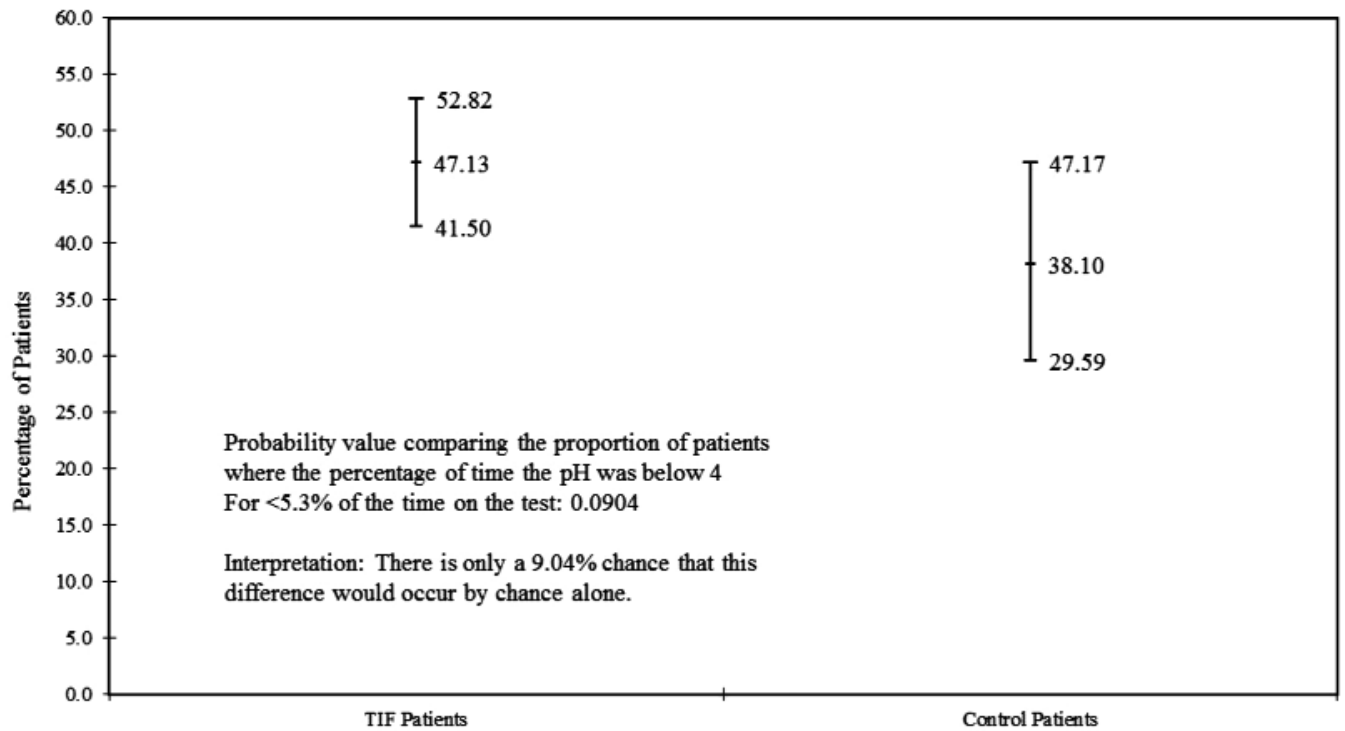

Figure 2. $\mathrm{pH}$ Test Results/Upright Position/Percentage of Patients Who had a pH Below $4<5.3 \%$ of the Time on the Test (Percentage with 95\% binomial confidence intervals/2-sided probability value from the Fisher's exact test)

\section{PPI Utilization}

Consistent with long-term follow-up studies spanning several years, patients who do not experience a significant level of symptomatic relief will withdraw and not return for follow-up evaluations. The results at 3 years showed equipoise for several of the outcome measures between the PPI and TIF 2.0 group, but the patients who did not undergo the TIF 2.0 procedure continued to take higher doses of PPIs compared to the TIF 2.0 patients. Figures 3 and

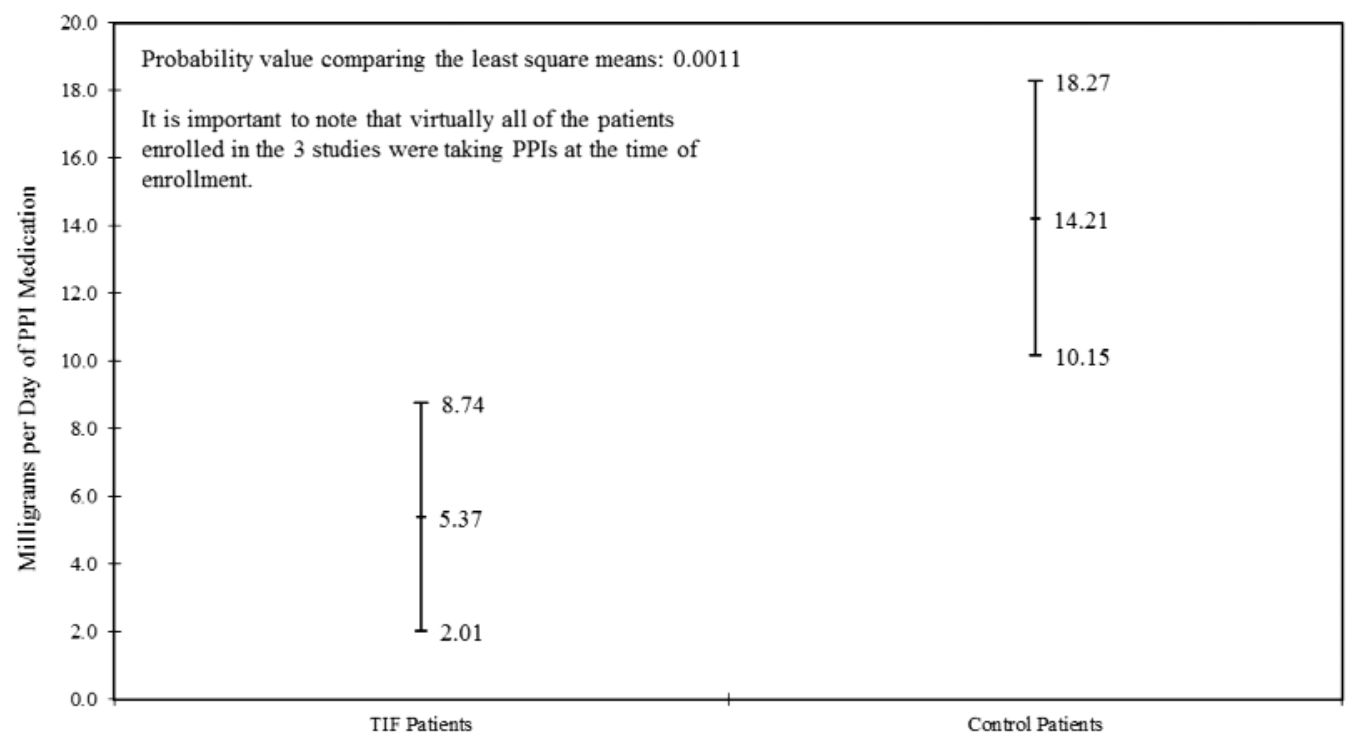

Figure 3. Summary of the Last Intra-patient Observation of PPI Usage (mg/day) by Treatment (Least Square Means with 95\% confidence intervals) 


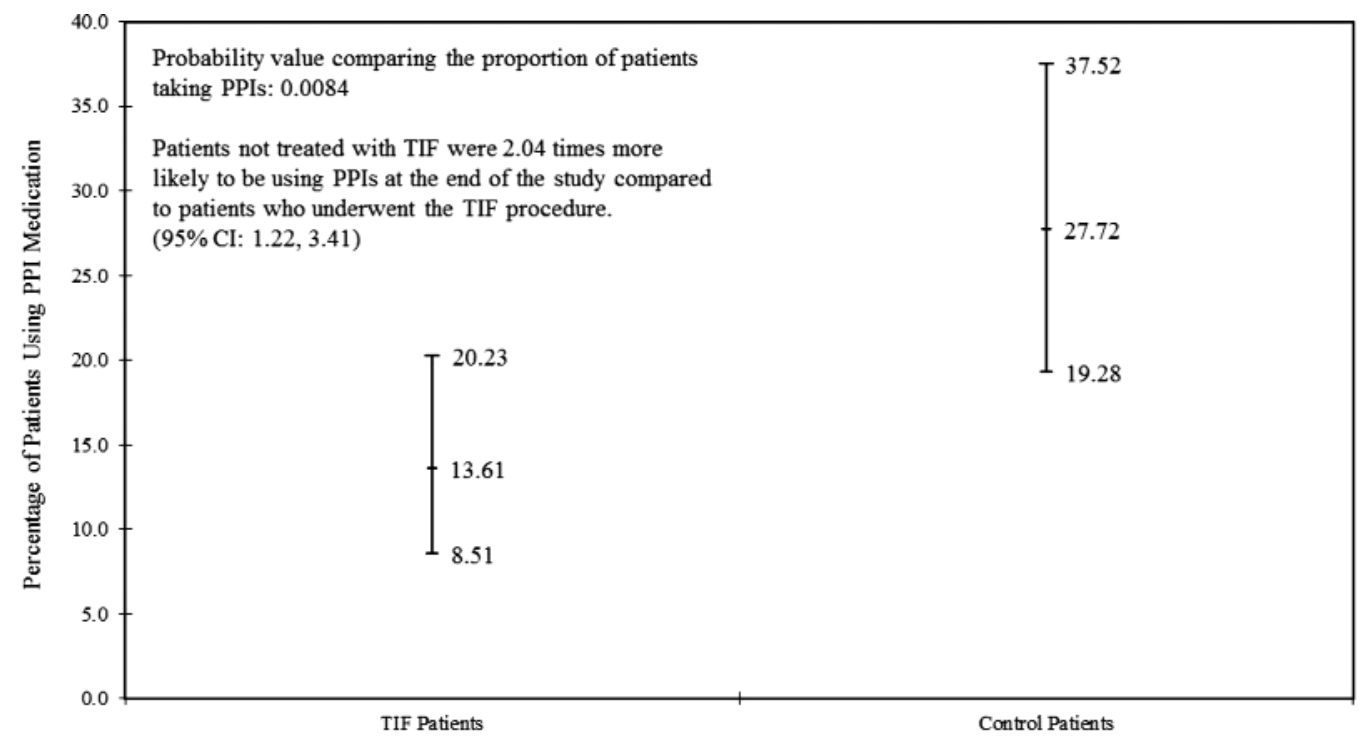

Figure 4. Summary of the Last Intra-patient Observation of PPI Usage ( $>0 \mathrm{mg} /$ day) by Treatment (Percentage with 95\% binomial confidence intervals/2-sided probability value from the Fisher's exact test)

4 show that the dose per day of PPIs taken at the time of last observation was higher for patients randomized to PPIs compared to patients randomized to the TIF 2.0 group. The group mean (95\% confidence limits) was $8.0 \mathrm{mg}$ per day $(0.54,15.45)$ for the TIF 2.0 group and $15.8 \mathrm{mg}(6.42,25.15)$ for the PPI group. The probability value was not significant relative to a type 1 error rate of $5 \%$ using an analysis of variance test $(p=0.1967)$ or a nonparametric Wilcoxon Two-Sample test with the normal approximation $(p=0.5103)$.

\section{Quality of Life}

The results of the analyses comparing the health-related quality of life scores (HRQL) scores at 3 years while off PPIs did not differ significantly between the TIF 2.0 and PPI groups (see Table 4). The group mean $(95 \%$ confidence limits) was $6.93(0.51,13.34)$ for the TIF 2.0 group and $10.1(1.73,18.39)$ for the

PPI group. The probability value was not significant relative to a type 1 error rate of $5 \%$ using an analysis of variance test $(p=0.5501)$ or a non-parametric Wilcoxon Two-Sample test with the normal approximation $(p=0.6832)$. However, as previously stated, the population of patients who remained in the study at 3 years was a subset of those patients originally randomized and enrolled. The results from patients treated with and without TIF 2.0 procedures were compared after 1 year of follow-up. The last recorded observation was used for all patients. Given lower scores reflect a higher quality of life, the results clearly show that

TABLE 4. Endpoints

\begin{tabular}{lccc}
\hline Parameter & PPI & TIF 2.0 & Probability Value \\
\hline Percentage of patients not taking medication for the condition at 36 months & 68.42 & 73.33 & 0.7536 \\
\hline $\begin{array}{l}\text { Percentage of patients with esophagitis at 36 months } \\
\begin{array}{l}\text { Percentage of patients who reported they were dissatisfied with the outcome } \\
\text { of the treatment at 36 months }\end{array}\end{array}$ & 7.14 & 14.81 & 0.6448 \\
\hline
\end{tabular}


patients randomized to receive TIF 2.0 had a significant improvement in their quality of life. Non-TIF 2.0 patients had no change in their quality of life status from baseline, evidenced by a mean reduction from baseline of 0.1 units and a median reduction of zero. TIF 2.0 patients had a mean reduction from baseline of 24 units and a median reduction of 23 units. Comparing the changes from baseline between the randomized treatment groups revealed a highly significant difference in favor of a quality of life improvement for TIF 2.0 patients 1 year after the procedure $(\mathrm{p}<0.0001)$.

\section{Crossover}

A significant proportion of the patients randomized to control (PPIs) either crossedover to TIF 2.0 or did not attend a substantive number of visits beyond 6-months. While results continued to improve for patients who underwent the TIF 2.0 procedure through 3 years, there is simply no contemporaneous control group for comparison at the same time points for the control patients. A significant proportion of patients, randomized to receive PPIs treatment alone, elected to undergo the TIF 2.0 procedure because the administration of PPIs did not provide an adequate level of relief.

\section{Discussion}

The EsophyX device used in the TIF 2.0 procedure, cleared by the US Food and Drug Administration in 2007 provides an opportunity to create an esophago-gastric fundoplication via an endoscopic approach. Our analysis of the three RCTs demonstrated improvement in objective outcomes (esophageal $\mathrm{pH}$ and reduction of PPI utilization) and subjective outcomes (improvement of patient quality of life).

The results from our current meta-analysis are important recognizing issues with the prior published reports. A recent published metaanalysis (based on analysis of RCT and prospective observational studies) on the TIF procedure with EsophyX device (11) concluded that the efficacy of the procedure decreased over time; however, this analysis included data from studies using earlier iterations of the TIF procedure, specifically ELF, which consisted in gastro-gastric plications below the $\mathrm{Z}$ line) and devices that should have been excluded, as they are not used anymore. In addition, it is possible that not all the RCTs should have been included $(12,13)$. The study by Witteman (4) for example, included patients with -Hill Grade III and IV- that are an absolute contraindication to undergo the TIF procedure. Results of an interim analysis based on an ongoing trial were reported by Witteman et al. (4); the analysis was conducted in only half of the overall study participants. Consequently, the analysis reported by Witteman et al was underpowered and, as the authors concluded, results should be interpreted with caution. In addition, the RCTs included studies with different designs - the Trad study (TEMPO) randomized TIF 2.0 procedures compared to PPI, while the Hunter (RESPECT) and Håkansson studies randomized TIF 2.0 procedure versus sham endoscopic procedure. The mixing of outcome data from different study designs likely lead to confounding results during the analysis.

The authors of previous research focused their main results on subjective outcomes such as poorly defined patient satisfaction, and usage of PPI therapy combining outcomes from different time points between 6 and 36 months post-procedure. A more logical presentation would have been to focus on objective data including total percentage time the esophageal $\mathrm{pH}$ was less than 4, discontinuation or reduction of PPI therapy, and differences in HRQL as we have done here using only data from peer-reviewed RCTs. Importantly, the outcome data did not differ from patients who remained on PPI therapy.

The authors stated that PPI usage increased over time post-TIF procedure, but did not perform a careful analysis of how PPI usage was determined. Prior literature has demonstrated that many patients resume PPI therapy without objective documentation of recurrent GERD and for symptoms other than GERD.14 A large 
percentage of patients remain on PPI therapy despite objective data showing the absence of GERD.

Our current updated meta-analysis has several strengths. We analyzed outcomes on a per-patient basis that allowed us to collect outcomes based on the amount of time that patients were available for data collection. The outcomes data collected therefore ranged from 6 to 36 months. Indeed, a recent publication based on results from the TEMPO trial at 36 months, nine patients demonstrated ongoing efficacy from the procedure at 36 months, including $\mathrm{pH}$ control, discontinuation of PPI therapy, and healing of EE. Further data regarding the efficacy of this procedure beyond 3 years will be useful to advise patients of expectations for symptom control.

This analysis suggests that the TIF 2.0 procedure controls symptoms and allows discontinuation of PPI use at rates similar to traditional surgical techniques with an improved safety profile and fewer long-term side-effects. Similarly, the TIF 2.0 procedure provides benefits of PPI use without systemic exposure to that classification of medications which may reduce risks associated with longterm exposure. Both aspects have positive implications for patients managing their chronic GERD condition.

\section{Conclusion}

In summary, this meta-analysis of RCT data demonstrates that for patients with chronic refractory GERD on adequate PPI therapy who desire endoscopic therapy, the TIF 2.0 procedure with EsophyX device offers excellent short and long-term symptomatic relief for the majority of chronic GERD patients who are appropriate candidates for the procedure.

\section{Acknowledgement}

Dr. Lauren Gerson passed away July 17, 2017. The co-authors appreciate her time on this project, analyzing data and preparing this manuscript. We submit this to honor her memory and contribute to her legacy of a career filled with many published meta-analyses.

\section{Authors' Contributions}

Concept and design: Gerson L, Lobonțiu, A;

Analysis and interpretation of data: Gerson L, Stouch B, Lobonțiu A;

Drafting of the article: Gerson L, Stouch B, Lobonțiu A;

Critical revision of the article for important intellectual content: Gerson L, Stouch B, Lobonțiu A;

Final approval of the article: Gerson L, Stouch B, Lobonțiu A;

Statistical expertise: Gerson L, Stouch B, Lobonțiu A;

Collection and assembly of data: Gerson L, Stouch B, Lobonțiu A;

\section{Conflict of interests}

Adrian Lobontiu is Chief Medical Officer of EndoGastric Solutions.

Financial support and sponsorship: None.

\section{References}

1. Chen KY, Lou HY, Lin HC, Lee SH. Seasonal variation in the incidence of gastroesophageal reflux disease. Am J Med Sci. 2009; 338(6):453-8.

2. Cleveland Clinic Digestive Health Team (April 15, 2014). Heartburn? Lifestyle Changes to Reduce Acid Reflux Symptoms. Retrieved from https://health.clevelandclinic.org/2014/04/heartburn-lifestyle-changes-to-reduce-acid-reflux-symptoms/

3 Galmiche JP, Hatlebakk J, Attwood S, Ell C, Fiocca R, Eklund S, Lțngström G, et al. Laparoscopic antireflux surgery vs esomeprazole treatment for chronic GERD: the LOTUS randomized clinical trial. JAMA. 2011;305(19):1969-77.

4. Witteman BP, Conchillo JM, Rinsma NF, Betzel B, Peeters A, Koek GH, et al. Randomized controlled trial of transoral incisionless fundoplication vs. proton pump inhibitors for treatment of gastroesophageal reflux disease. Am J Gastroenterol. 2015;110(4): 531-42.

5. Trad KS, Barnes WE, Simoni G, Shughoury AB, Mavrelis PG, Raza $M$, et al. Transoral Incisionless Fundoplication Effective in Eliminating GERD Symptoms in Partial Responders to Proton Pump Inhibitor Therapy at 6 Months: The TEMPO Randomized Clinical Trial. Surg Innov. 2015;22(1):26-40.

6. Trad KS, Fox MA, Simoni G, Ahmad B, Shughoury AB, Mavrelis PG, et al. Efficacy of Transoral Fundoplication For Treatment of Chronic Gastroesophageal Reflux Disease Incompletely Controlled with High-Dose PPI Therapy: A Randomized, Multicenter, Open Label, 
Crossover Study. BMC Gastroenterol. 2014;14(1):174.

7. Trad KS, Fox MA, Simoni G, Shughoury AB, Mavrelis PG, Raza M, et al. Transoral Fundoplication Offers Durable Symptom Control for Chronic GERD: 3-Year Report from the TEMPO Randomized Trial with a Crossover Arm. Surg Endosc. 2016 Sep 21. [Epub ahead of print]

8. Hunter JG, Kahrilas PJ, Bell RCW, Wilson EB, Trad KS, Dolan JP, et al. Efficacy of transoral fundoplication vs. omeprazole for treatment of regurgitation in a randomized controlled trial. Gastroenterology. 2015;148(2):324-333.

9. Håkansson B, Montgomery M, Cadiere GB, Rajan A, Bruley des Varannes S, Lerhun M, et al. Randomised clinical trial: transoral incisionless fundoplication vs. sham intervention to control chronic GERD. Aliment Pharmacol Ther. 2015;42(11-12):1261-70. doi: 10.1111/apt.13427. Epub 2015 Oct 13.

10. Jadad AR, Moore RA, Carroll D, Jenkinson C, Reynolds DJ, Gavaghan
DJ, et al. Assessing the quality of reports of randomized clinical trials: is blinding necessary? Control Clin Trials. 1996;17(1):1-12.

11. Huang X, Chen S, Zhao H, Zeng X, Lian J, Tseng Y, Chen J. Efficacy of transoral incisionless fundoplication (TIF) for the treatment of GERD: a systematic review with meta-analysis. Surg Endosc. 2016 Aug 5. [Epub ahead of print].

12. Cadière GB, Rajan A, Germay 0 , Himpens J. Endoluminal fundoplication by a transoral device for the treatment of GERD: a feasibility study. Surg Endosc. 2008 Feb; 22(2):333-42.

13. Cadière GB, Van Sante N, Graves JE, Gawlicka AK, Rajan A. Two-year results of a feasibility study on antireflux transoral incisionless fundoplication (TIF) using EsophyX. Surg Endosc. 2009; 23(5): 957-64.

14. Lødrup A, Pottegård A, Hallas J, Bytzer P. Use of proton pump inhibitors after antireflux surgery: a nationwide register-based follow-up study. Gut. 2014;63(10):1544-9. 